\title{
Effect of Decision Variables on Irrigation Performance Parameters Under Different Irrigation Systems
}

\section{Gudeta Genemo}

Oromia Agricultural Research Institute, Bako Agricultural Engineering Research Center, Bako, Ethiopia

\section{Email address:}

4genemo@gmail.com

\section{To cite this article:}

Gudeta Genemo. Effect of Decision Variables on Irrigation Performance Parameters Under Different Irrigation Systems. International Journal of Sustainable Development Research. Vol. 7, No. 3, 2021, pp. 50-55. doi: 10.11648/j.ijsdr.20210703.11

Received: July 15, 2021; Accepted: July 26, 2021; Published: August 2, 2021

\begin{abstract}
Furrow irrigation has low irrigation performances due to inescapable irrigation water loss through runoff and deep percolation. This study was conducted under small farmers to study combined influence of furrow irrigation flow rate and irrigation systems on irrigation performance parameters. The purposes of study were to evaluate outcome of furrow irrigation flow rate and irrigation systems on application efficiency, distribution efficiency, storage efficiency and deep percolation loss using field experiment. The field experiment had two factors of three furrow irrigation system (AFI, FFI \& CFI) and four furrow irrigation inflow rate $(\mathrm{Q} 1, \mathrm{Q} 2, \mathrm{Q} 3$ \& Q4). Field experimental plot was made in randomized complete block design with factorial arrangement of twelve treatment combinations and three replications. The collected field variables were management variables (irrigation performances) and site variables (soil type, soil moisture and furrow bed slope). The results show that, influence of furrow irrigation inflow rate and irrigation systems on irrigation performance parameters were highly significant $(\mathrm{P}<0.01)$. However, no significant difference among irrigation systems were observed in case of distribution uniformity $(\mathrm{Du})$ expect furrow inflow rate. Interaction effect of irrigation systems and furrow inflow rate on irrigation performance parameter such as Ea, Du and DP were significant $(\mathrm{p}<0.05)$ expect storage efficiency. The highest values of distribution uniformity were 93.45\% was observed under CFIQ4 treatment combination while the least value of distribution uniformity was $81.58 \%$ was observed under AFIQ1 treatment combination. The highest values of application efficiency $68.35 \%$ was observed under AFIQ4 treatment combination and the least value of application efficiency 53.60\% was observed for CFIQ1 treatment combination. However, the highest values of deep percolation loss $46.60 \%$ was obtained under CFIQ1 treatment combination and the least value of deep percolation loss $31.65 \%$ was found under AFIQ4 treatment combination. It can be concluded that best result in improving application efficiency, distribution efficiency, and storage efficiency with the reduction of deep percolation loss were obtained under Alternative furrow irrigation with maximum non erosive furrow inflow rate.
\end{abstract}

Keywords: Irrigation System, Inflow Rate, Performance Parameter, Deep Percolation Loss

\section{Introduction}

In surface irrigation, furrow irrigation is the most widely used and considered as low water application efficiency and distribution uniformity. Proper design and best management of the furrow irrigation can led to increased water use efficiency and cultivated area [1]. Inappropriate management and design are the central causes for deprived performance of furrow irrigation systems. However, furrow irrigation method has the shortcoming of inducing soil erosion in the irrigated farms there by posing a great threat to sustainability of surface irrigated agricultural productivity. The rate and severity of soil loss is not ever a function of specific element, nevertheless, interactive effect of field parameters, design variables and irrigation management systems.

Even though, its application efficiency remaining relatively low not sufficient exertion is being made to keep modifying its management and efficiency. Still now, Irrigators face Severe rivalry for limited water resources from other divisions of economic activity But, the query is which type of furrow irrigation methods (conventional, Alternative and fixed furrow irrigation system) used with combination of furrow irrigation decision variables are urgent problem under small holder farmer in order to maximize benefits and minimize water use.

In Ethiopia, irrigation efficiencies are normally low, order of 25 to $50 \%$ and owing to this, problem of rising of water table 
and salinity was now emerging [2]. In the furrow irrigation system, inflow rates are the principal management and design variables influencing irrigation performances [3]. Until now, information gap that still exist on the combined effects of furrow irrigation Inflow rate and irrigation systems on irrigation efficiency to inform decision making on furrow irrigation. Therefore, the purpose of this paper was to investigate the effect of furrow irrigation decision variables on performance parameters under different irrigation systems.

\section{Materials and Methods}

\subsection{Description of the Study Area}

The field experiment was conducted at Bako Tibe woreda, West Shewa Zone about $250 \mathrm{~km}$ away from Addis Ababa. Field experiment was located an altitude of 1590 meters above sea level and lies in $9^{\circ} 06^{\prime} \mathrm{N}$ and $37^{\circ} 09^{\prime} \mathrm{E}$ Latitude and longitude respectively.

\subsection{Experimental Design and Treatment}

Treatment considered for this experiment was two factor i.e., three irrigation systems and four levels of furrow irrigation inflow rates. Irrigation systems are AFI, FFI and
CFI and four levels of furrow irrigation inflow rates are Q1, Q2, Q3 and Q4. These flow rates were prepared by rating of $50 \%, 70 \%, 85 \%$ and $100 \%$ of the maximum non-erosive flow rate. The amount of water applied to the field was measured by using Parshall Flume. The experimental plots were prescribed in randomized complete blocks design with $3 \times 4$ factorial experiments and three replications.

Table 1. Combination of Treatment.

\begin{tabular}{lllll}
\hline \multirow{2}{*}{$\begin{array}{l}\text { Irrigation } \\
\text { system }\end{array}$} & \multicolumn{4}{l}{ Furrow irrigation inflow rate } \\
\cline { 2 - 5 } Q1 & Q2 & Q3 & Q4 \\
\hline AFI & $50 \%$ Qamx & $70 \%$ Qmax & $85 \%$ max & $100 \%$ max \\
FFI & $50 \%$ Qamx & $70 \%$ Qmax & $85 \%$ max & $100 \%$ Qmax \\
CFI & $50 \%$ Qamx & $70 \%$ Qmax & $85 \%$ Qmax & $100 \%$ Qmax \\
\hline
\end{tabular}

Where; AFI=Alternative furrow irrigation, $\mathrm{FFI}=$ Fixed furrow irrigation, $\mathrm{CFI}=$ Conventional furrow, $\mathrm{Q} 1=50 \%$ Qmax, $\mathrm{Q} 2=70 \% \mathrm{Qmax}, \mathrm{Q} 3=85 \% \mathrm{Qmax}$, $\mathrm{Q} 4=100 \%$ Qmax, respectively.

\subsection{Collection of Soil Sample and Analysis Methods}

Soil Physical properties of experimental site such as bulk density, texture, infiltration, field capacity and permanent wilting point were done by using core sampler method, pipette method, Inflow out flow method, pressure plate apparatus, respectively.

Table 2. Soil properties of the experimental site.

\begin{tabular}{|c|c|c|c|c|c|c|c|c|}
\hline \multirow{2}{*}{ Soil Depth } & \multirow[b]{2}{*}{ BD $\left(\mathrm{g} / \mathrm{cm}^{3}\right)$} & \multirow[b]{2}{*}{ FC (\%) } & \multirow[b]{2}{*}{ PWP (\%) } & \multirow[b]{2}{*}{ TAW (mm/m) } & \multicolumn{3}{|c|}{ Particle size distribution (\%) } & \multirow{2}{*}{ Textural class } \\
\hline & & & & & Sand & Silt & Clay & \\
\hline $0-20 \mathrm{~cm}$ & 1.29 & 31.32 & 16.21 & 194.92 & 31 & 34 & 35 & Clay loam \\
\hline $20-40 \mathrm{~cm}$ & 1.30 & 30.27 & 15.43 & 192.92 & 35 & 30 & 35 & Clay loam \\
\hline $40-60 \mathrm{~cm}$ & 1.31 & 29.3 & 13.54 & 206.5 & 31 & 30 & 39 & Clay loam \\
\hline Average & 1.30 & 30.30 & 15.06 & 198.11 & 32.33 & 31.33 & 36.33 & Clay loam \\
\hline
\end{tabular}

Note: $\mathrm{BD}=$ Bulk density, $\mathrm{FC}=$ Field capacity, $\mathrm{PWP}=$ permanent wilting point, $\mathrm{TAW}=$ total available water, $\mathrm{EC}=$ electrical conductivity

\subsection{Soil Moisture Determination}

For purpose performance evaluation the soil samples of each plot were collected before and two days after irrigation at the initial and midseason growth stages of the crop for performance from three points, Initial, mid $(1 / 2 \mathrm{~L})$, and end of the furrow (L) along furrow length from each plot at three depths (Table 2), using a soil auger.

\subsection{Field Evaluation Parameters}

\subsubsection{Determination of Furrow Characteristics}

For measuring Cross-sectional area of furrow at the inlet, a furrow profilometer was done from round bars with $8 \mathrm{~mm}$ in diameter and $500 \mathrm{~mm}$ length and $1200 \mathrm{~mm}$ wooden base. From these parameters characterizing the furrow geometry like depth of furrow, top width, mid-top width and base width of furrow were measured. Cross-sectional area at the inlet furrow (Ao) was determined from the manning equation and furrow geometry parameter coefficients [4].

$$
A_{o}=\left(\frac{n Q o}{60 \rho 1 S o^{0.5}}\right)^{1 / \rho 2}
$$

Where; $\rho_{2}=\frac{10}{3}-\frac{4 \gamma_{2}}{3} \boldsymbol{\delta}_{2}$ and $\rho_{1}=\frac{\boldsymbol{\delta}_{1}^{10 / 3}}{\gamma_{1}^{4 / 3}}$

The values of values of furrow shape parameters coefficients $\gamma_{1}, \gamma_{2}, \delta_{1}$ and $\delta_{2}$ can be computed based on known measurements of furrow geometry as described by [5].

\subsubsection{Infiltration Characteristics of the Soil}

Knowledge of infiltration characteristics of the soil is very important for design and management of furrow irrigation system, without it difficult to accurately judge system performance, application efficiency, and uniformity [4]. Twopoint method was used to calculate the infiltration characteristics based on the modified Kostiakov equation as shown equation (2)

$$
Z=\mathrm{K} \tau^{a}+\text { fo } \tau
$$

Where;

$\mathrm{Z}=$ the cumulative infiltration per unit length of furrow $\left(\mathrm{m}^{3} / \mathrm{m} / \mathrm{m}\right)$

$\tau=$ the intake opportunity time ( $\mathrm{min}$ ), for any point $\mathrm{X}$

$f o=$ the basic intake rate $\left(\mathrm{m}^{3} / \mathrm{min} / \mathrm{m}\right)$

$\mathrm{K}$ and $\mathrm{a}=$ Infiltration parameters 
Parameters of kostiakov Lewis equation ' $\mathrm{K}$ and $\mathrm{a}$ ' were determined by two-point method using a simple volume balance equation.

\subsection{Furrow Irrigation Decision Variables}

The maximum non-erosive furrow inflow rate was determined using the equation developed by [6]

$$
\mathrm{Q} \max =\frac{\alpha}{\mathrm{S}^{\beta}}
$$

Where; Qmax=Maximum furrow inflow rate $(1 / \mathrm{s})$

$\mathrm{S}=$ Furrow bed slope (\%)

$\alpha$ and $\beta$ are coefficients of parameters based on soil group

Table 3. Coefficient parameters for furrow maximum flow rate.

\begin{tabular}{lll}
\hline Soil group & $\boldsymbol{\alpha}(\mathbf{l} / \mathbf{s})$ & $\boldsymbol{\beta}$ \\
\hline Heavy textured soil & 0.892 & 0.937 \\
Medium heavy textured & 0.988 & 0.55 \\
Medium Texture & 0.613 & 0.733 \\
Light texture & 1.111 & 0.615 \\
Very Light texture & 0.665 & 0.548 \\
\hline
\end{tabular}

(Source: Hamad and Stringham [6])

The slope of the furrow was determined using line-level by measuring at $10 \mathrm{~m}$ interval along furrow length. The experimental plot had an average of furrow bed slope of $0.6 \%$ and clay loam in textural class which categorized as mediumheavy textured soil group [7]. Based on these the value of $\alpha$ and $\beta$ were determined (Table 3 ). Therefore the maximum nonerosive furrow inflow rate (Qmax) obtained above formula was $1.31 \mathrm{~L} / \mathrm{s}$ and the three levels of furrow inflow rate, $50 \%$, $70 \%, 85 \%$ and $100 \%$ of Qmax were $0.7,0.65,1.12$ and $1.31 \mathrm{~L} / \mathrm{s}$, respectively.

\subsection{Determination of Irrigation Performance Parameters}

\subsubsection{Application Efficiency (Ea): Was calculated as} Shown in Equation 4)

$$
\mathrm{Ea}=\frac{\mathrm{Zs}}{\mathrm{Z}} \times 100
$$

Where; $Z_{s}=$ depth of water retained in the root zone $(\mathrm{mm})$ $\mathrm{Z}=$ depth of water applied to the furrow $(\mathrm{mm})$

\subsubsection{Storage Efficiency (Es): Was Resolute as Shown Equation (5)}

$$
E s=\frac{Z S}{Z r e q} \times 100
$$

Where; $Z_{S}=$ depth of water stored in the root zone ( $\mathrm{mm}$ ) Zreq $=$ Water required in root zone prior to irrigation $(\mathrm{mm})$

\subsubsection{Distribution Uniformity (Du): Was Determined as Shown Equation (6)

$$
\mathrm{DU}=\frac{\mathrm{Zmin}}{\mathrm{Zav}} \times 100
$$

Where; $\mathrm{Zmin}=$ the minimum infiltrated depth $(\mathrm{mm})$ and Zav $=$ the mean of depths infiltrated over the furrow length (mm)

\subsubsection{Deep Percolation Loss: Was Determined as Shown Equation (7)}

$$
\mathrm{DP}=100-\mathrm{Ea}-\mathrm{RR}
$$

Since the study was conducted under farmers' field conditions, the furrows were closed-end (end dyked) and runoff ratio $(R R)$ was neglected.

\subsection{Method of Data Analysis}

The collected data were analyzed using SAS 9.0 statistical software. For comparing means of the treatments that indicated significant result, the least significant difference test at $5 \%$ and $1 \%$ probability level were applied.

\section{Results and Discussion}

\subsection{Infiltration Characteristics of the Soil}

The infiltration characteristics of the soil were determined by using inflow-out flow method. Average of basic infiltration rate was found to be $0.0000967 \mathrm{~m} / \mathrm{min}$ or $5.8 \mathrm{~mm} / \mathrm{hr}$ ), which is in the range value for clay loam [8]. The values of furrow geometric parameters and basic infiltration rate were used as input in the determination of infiltration parameters ' $\mathrm{k}$ and $\mathrm{a}$ ' in Kostiakov-Lewis equation. The infiltration parameters ' $\mathrm{k}$ and a' were found to be 3.64 $\mathrm{mm} / \mathrm{min}^{\mathrm{a}}$ and 0.47 respectively, using a volume balance method. Based on these, the depth of water infiltrated along furrow length determined using the following equation

$$
\mathrm{Z}=3.64 \mathrm{t}^{0.47}+0.0967 \mathrm{t}
$$

Where; $z=$ depth of water infiltrated along furrow length (mm) and

$\mathrm{t}=$ intake opportunity time $(\mathrm{min})$

\subsection{Effect of Furrow Inflow Rate on Irrigation Performance Parameters Under Different Irrigation Systems}

Analysis of variance indicated that (Table 4), the influence of furrow inflow rate and irrigation systems were highly significant $(\mathrm{p}<0.01)$ on irrigation performance parameters and their interaction were significant $(\mathrm{p}<0.05)$ expect storage efficiency.

Table 4. Analyses of variance for inflow rate and irrigation systems on irrigation Performance parameters.

\begin{tabular}{lllll}
\hline \multirow{2}{*}{ Source of variation } & \multicolumn{4}{l}{ Irrigation performance parameters } \\
\cline { 2 - 5 } & $\mathbf{E}_{\mathbf{a}}(\mathbf{\%})$ & $\mathbf{E}_{\mathbf{S}}(\mathbf{\%})$ & $\mathbf{D}_{\mathbf{U}}(\mathbf{\%})$ & $\mathbf{D P}(\mathbf{\%})$ \\
\hline Flow Rate (Q) & $37.6^{* *}$ & $49.5^{* *}$ & $30.68^{* *}$ & $37.6^{* *}$ \\
Irrigation system (IS) & $24.8^{* *}$ & $27.5^{* *}$ & $21.4^{* *}$ & $24.8^{* *}$ \\
Q X IS & $3.15^{*}$ & $2.30^{\text {ns }}$ & $5.40^{* *}$ & $3.15^{*}$ \\
CV & 8.61 & 2.82 & 10.45 & 9.8 \\
LSD (0.05) & 2.75 & 1.89 & 3.45 & 2.75 \\
\hline
\end{tabular}

Where; ${ }^{\text {NS }}$ Non significant, ${ }^{*}$ Significant, ${ }^{* *}$ Highly significant, Q=Flow rate, Q $\mathrm{X}$ IS=Interaction of irrigation system and flow rate, $\mathrm{E}_{\mathrm{a}}=$ Application Efficiency, $E_{S}=$ Storage Efficiency, $D_{U}=$ Distribution uniformity, $D_{\mathrm{P}}=$ Deep percolation loss 


\subsubsection{Application Efficiency}

Influence of furrow irrigation inflow rate and irrigation systems on application efficiency $\left(\mathrm{E}_{\mathrm{a}}\right)$ were highly significant at $(\mathrm{P}<0.01)$ (Table 4). Minimum $\mathrm{E}_{\mathrm{a}}$ was obtained under conventional furrow irrigation which was $58.32 \%$ and maximum $\mathrm{E}_{\mathrm{a}}$ was obtained under $\mathrm{AFI}$ which was $65.43 \%$ (Table 5). This might be due to encouragement of lateral movement of water across the ridge, which reduces the forward movement of water along the furrow compared to CFI system. This minimizes the loss of irrigation water due to deep percolation loss below the effective root zone of the crop. This is consistent with $[9,10]$.

Table 5. Interaction effect of furrow inflow rate and irrigation systems on Application Efficiency.

\begin{tabular}{llllll}
\hline \multirow{2}{*}{$\begin{array}{l}\text { Irrigation } \\
\text { systems }\end{array}$} & \multicolumn{4}{l}{ Mean of Application Efficiency (\%) } & \multirow{2}{*}{ Mean } \\
\cline { 2 - 5 } & \multicolumn{2}{l}{ Furrow irrigation inflow rate (1/s) } & \\
\cline { 2 - 5 } & $\mathbf{Q 1}$ & $\mathbf{Q 2}$ & $\mathbf{Q 3}$ & $\mathbf{Q 4}$ & \\
\hline AFI & $62.75 \mathrm{a}$ & $64.86 \mathrm{e}$ & $65.75 \mathrm{c}$ & $68.35 \mathrm{~s}$ & $65.43 \mathrm{~m}$ \\
FFI & $61.85 \mathrm{~b}$ & $63.45 \mathrm{n}$ & $65.47 \mathrm{j}$ & $67.35 \mathrm{t}$ & $64.53 \mathrm{~m}$ \\
CFI & $53.60 \mathrm{~d}$ & $57.35 \mathrm{k}$ & 60.891 & $61.45 \mathrm{~m}$ & $58.32 \mathrm{k}$ \\
Mean & $59.40 \mathrm{k}$ & $61.89 \mathrm{~b}$ & $64.04 \mathrm{e}$ & $65.72 \mathrm{j}$ & 62.76 \\
LSD (0.05) & & 1.58 & & & \\
CV (\%) & & 4.65 & & & \\
\hline
\end{tabular}

* Means of the same letter are not significantly different

The minimum $\mathrm{E}_{\mathrm{a}}$ was obtained under small flow rate which was $59.40 \%$ and maximum Ea was obtained under maximum flow rate which was $65.42 \%$ (Table 5). This might be due to small furrow inflow rate has a slow advance time that leads to made maximum deep percolation loss, which contributes to decrease application efficiency and maximum flow rate has faster advance, which contribute to minimize deep percolation loss and increasing the application efficiency. This report was agreed with [11].

\subsubsection{Storage Efficiency}

Effect of furrow irrigation inflow rate and irrigation systems on storage efficiency (Es) were highly significant at $(\mathrm{P}<0.01)$ (Table 4). But interaction between furrow irrigation flow rate and irrigation systems on storage efficiency were non-significant $(\mathrm{P}<0.05)$. The minimum $\mathrm{E}_{\mathrm{S}}$ was obtained under conventional furrow irrigation which was $75.04 \%$ and maximum $E_{S}$ was obtained under Alternative furrow irrigation which was $78.12 \%$ (Table 6). The $\mathrm{E}_{\mathrm{S}}$ of conventional furrow irrigation system was significantly different from Alternative furrow irrigation, But there was no significant difference between AFI and FFI systems (Table 5). This is because of the irrigation system, as all furrows was getting an chance of irrigated at once in conventional furrow irrigation system, also it was turn by turn in AFI. The minimum ES was obtained under maximum flow rate which was $74.07 \%$ and maximum $\mathrm{E}_{\mathrm{S}}$ was obtained under small flow rate which was $80.22 \%$. This trend was agreed with [12].

Table 6. Effect of furrow inflow rate and irrigation systems on Storage Efficiency.

\begin{tabular}{|c|c|c|c|c|c|c|c|}
\hline \multirow{2}{*}{ Storage Efficiency } & \multicolumn{3}{|c|}{ Irrigation Systems } & \multicolumn{4}{|c|}{ Furrow irrigation inflow rate } \\
\hline & AFI & FFI & CFI & $\mathbf{Q}_{1}$ & $\mathbf{Q}_{2}$ & $\mathbf{Q}_{3}$ & $\mathbf{Q}_{4}$ \\
\hline $\begin{array}{l}\mathrm{E}_{\mathrm{S}} \\
\text { Mean } \\
\text { CV (\%) } \\
\operatorname{LSD}(0.5)\end{array}$ & $78.12 \mathrm{ba}$ & $77.70 \mathrm{ba}$ & $75.04 \mathrm{~cd}$ & $\begin{array}{l}80.22 \mathrm{~d} \\
76.95 \\
6.86 \\
2.35\end{array}$ & $77.70 \mathrm{~b}$ & $75.83 \mathrm{c}$ & $74.07 f$ \\
\hline
\end{tabular}

* Means of the same letter are not significantly different

Where; AFI=Alternative furrow irrigation, FFI=Fixed furrow irrigation, $\mathrm{CFI}=$ Conventional furrow, Q1=50\% Qmax, Q2=70\% Qmax, Q3=85\% Qmax, Q4=100\% Qmax

\subsubsection{Distribution Uniformity}

ANOVA Reveal that effect of furrow irrigation inflow rate and irrigation systems on distribution uniformity $(\mathrm{Du})$ were highly significant $(\mathrm{P}<0.01)$ (Table 4$)$. As shown on Table 8, $\mathrm{D}_{\mathrm{U}}$ CFI system and $\mathrm{Q} 4$ were significantly different from AFI system and under different furrow irrigation inflow rate, respectively. But, no significant difference between CFI, FFI and AFI (Table 7). This is consistent with [13]. However, furrow irrigation inflow rate was significantly affected by distribution uniformity. The minimum distribution uniformity was obtained under small flow rate which was $84.18 \%$ and maximum distribution uniformity was obtained under larger flow rate which was $90.98 \%$ (Table 7). This is due to increases of furrow flow rates reduces the difference in wetting along the furrow length contribute to increases the distribution uniformity. This trend was agreed with [14].

Interaction between furrow irrigation flow rate and irrigation systems on $\mathrm{D}_{U}$ were significant $(\mathrm{P}<0.05)$ (Table 4). Distribution uniformity of AFI system at inflow rate of Q1 was significantly affected the remaining furrow inflow rate under different irrigation system. Furthermore, interaction of Convectional furrow irrigation (CFI) with maximum flow rate (Q4) give better distribution uniformity $93.45 \%$ which was significantly different from the enduring furrow irrigation inflow rate. Distribution uniformity under different furrow irrigation inflow rate increases due to soil water potential difference and variation of intake opportunity time.

Table 7. Interaction effect of furrow inflow rate and irrigation systems on distribution uniformity.

\begin{tabular}{llllll}
\hline \multirow{2}{*}{$\begin{array}{l}\text { Irrigation } \\
\text { systems }\end{array}$} & \multicolumn{4}{l}{ Mean of distribution uniformity (\%) } & \multirow{2}{*}{ Mean } \\
\cline { 2 - 5 } & \multicolumn{2}{l}{ Furrow irrigation inflow rate (1/s) } & \\
\cline { 2 - 5 } & $\mathbf{Q 1}$ & $\mathbf{Q 2}$ & $\mathbf{Q 3}$ & $\mathbf{Q 4}$ & \\
\hline AFI & $81.58 \mathrm{~h}$ & $88.45 \mathrm{~b}$ & $90.85 \mathrm{r}$ & $91.25 \mathrm{e}$ & $88.03 \mathrm{c}$ \\
FFI & $85.68 \mathrm{j}$ & $86.97 \mathrm{~d}$ & $89.23 \mathrm{n}$ & $91.45 \mathrm{e}$ & $88.33 \mathrm{c}$ \\
CFI & $86.45 \mathrm{~m}$ & $87.68 \mathrm{~d}$ & $87.69 \mathrm{~d}$ & $93.45 \mathrm{~b}$ & $88.23 \mathrm{c}$ \\
Mean & $84.57 \mathrm{~s}$ & $87.70 \mathrm{t}$ & $89.26 \mathrm{n}$ & $92.05 \mathrm{~b}$ & 88.20 \\
LSD (0.05) & & 1.89 & & & \\
CV (\%) & & 3.50 & & & \\
\hline
\end{tabular}

* Means of the same letter are not significantly different 


\subsubsection{Deep Percolation Loss}

ANOVA Reveal that consequence of furrow irrigation inflow rate and irrigation systems on deep percolation loss were highly significant $(\mathrm{P}<0.01)$. The minimum deep percolation loss was obtained under Alternative furrow and fixed furrow irrigation which was 34.57 and $35.47 \%$, respectively and maximum deep percolation loss was obtained under conventional furrow irrigation which was $41.68 \%$ (Table 8 ). While, there was no significant difference between AFI and FFI systems (Table 8). This report was agreed with [10]. The minimum deep percolation loss was obtained under larger flow rate which was $38.55 \%$ and maximum deep percolation loss was obtained under small flow rate which was $46.60 \%$ (Table 8). Similarly,[15] have got a decreasing trend of deep percolation loss as furrow inflow rate increases. Combined effect of irrigation systems and furrow irrigation inflow rate on deep percolation loss was significant $(p<0.05)$ (Table 4). In this study, the highest deep percolation loss $46.40 \%$ was observed for treatment interaction of conventional furrow irrigation (CFI) minimum flow rate (Q1). The lowest application deep percolation loss $31.65 \%$ was observed in the interaction of Alternative furrow irrigation (AFI) with maximum flow rate (Q4) (Table 8).

Table 8. Interaction effect of furrow inflow rate and irrigation systems on Deep percolation loss.

\begin{tabular}{llllll}
\hline \multirow{2}{*}{$\begin{array}{l}\text { Irrigation } \\
\text { systems }\end{array}$} & \multicolumn{5}{l}{ Mean of Deep Percolation loss (\%) } \\
\cline { 2 - 6 } & \multicolumn{5}{l}{ Furrow irrigation inflow rate (1/s) } \\
\cline { 2 - 6 } & Q1 & Q2 & Q3 & Q4 & Mean \\
\hline AFI & $37.25 \mathrm{~g}$ & $35.14 \mathrm{~d}$ & $34.25 \mathrm{j}$ & $31.65 \mathrm{n}$ & $34.57 \mathrm{f}$ \\
FFI & $38.15 \mathrm{~g}$ & $36.55 \mathrm{~d}$ & $34.53 \mathrm{j}$ & $32.65 \mathrm{n}$ & $35.47 \mathrm{f}$ \\
CFI & $46.40 \mathrm{f}$ & $42.65 \mathrm{c}$ & $39.11 \mathrm{k}$ & $38.55 \mathrm{r}$ & $41.68 \mathrm{c}$ \\
Mean & $40.60 \mathrm{~b}$ & $38.11 \mathrm{~g}$ & $35.96 \mathrm{~d}$ & $34.28 \mathrm{j}$ & 37.24 \\
LSD (0.05) & & 1.58 & & & \\
CV (\%) & \multicolumn{5}{c}{4.65} \\
\hline
\end{tabular}

* Means with the same letter are not significantly different

\section{Conclusion and Recommendation}

Understanding the irrigation efficiencies for different types of irrigation systems would help farmers made decisions about choice of irrigation management which improve their production and productivity. Considering above issue, study was conduct to investigate influence of variable furrow irrigation inflow rate under different irrigation systems on irrigation performance parameters. The result shows that, influence of furrow irrigation inflow rate and irrigation systems on application efficiency (Ea) and storage efficiency (Es), and deep percolation loss (Dp) were highly significant $(\mathrm{P}<0.01)$. However, no significant difference among irrigation systems were observed in case of distribution uniformity expect furrow inflow rate. The results of this study showed that better performance in improvement of application efficiency, distribution efficiency, storage efficiency with reduction of deep percolation loss were obtained under Alternative furrow irrigation system with combination of maximum non erosive furrow inflow rate.

\section{Acknowledgements}

Thanks to all persons help me during conducting research. Special thanks to Farmers Ademu and Fayera to assists me in research, Laboratory technicians of oromia water work, design and supervision. Special thanks to Agricultural Engineering Research Directorate, Oromia Agricultural Research Institute.

\section{References}

[1] Sunil Garg, B. S. Gulati, M. R Kaushal and A. K. Jain. 2006. Development of Relationship between Performance Irrigation Parameters and Furrow Irrigation Design Variables, Yield and Net Returns. Journal of Agricultural Engineering Vol. 43 (2).

[2] EARO (Ethiopian Agricultural Research Organization). 2002. Concept Paper on Agricultural Water Management. Addis Ababa, Ethiopia. 15 pp.

[3] Eldeiry, A., Garcia, L. A, El-Zaher, A. S, and Kiwan, M. E. 2005. Furrow irrigation system design for clay soils in arid regions. Appl. Eng. Agric. 21: 411-420.

[4] Walker, W. R. and Skogeroboe G. V. 1987. Surface Irrigation: Theory and Practice. Prentice Hall, New Jersey; $386 \mathrm{P}$.

[5] Walker, W. R. 2003. SIRMOD III Surface Irrigation Simulation, Evaluation, and Design, Guide and Technical Documentation. Utah State University.

[6] Hamad, N. S., and Stringham, G. E. 1978. Maximum nonerosive furrow irrigation stream size. Journal of Irrigation and Drainage Division. American Society of Agricultural Engineers, 104: 275-279.

[7] FAO (Food and Agricultural Organization). 1991. A Manual for the Design and Construction of Water Harvesting Schemes for Plant Production. Rome.

[8] Walker, W. R. 1989. Guidelines for Designing and Evaluating Surface Irrigation System: Irrigation and drainage paper No. 45. FAO, Rome.

[9] Adisu Tadese Eba. 2018. The Impact of Alternate Furrow Irrigation on Water Productivity and Yield of Potato at Small Scale Irrigation, Ejere District, West Shoa, Ethiopia. J Plant Sci Agric Res. Vol. 2 No. 2: 16.

[10] Lemma Teklu Kumsa. 2020. Effect of Deficit Furrow Irrigation on Yield and Water Productivity of Tomato in Central Rift Valley Intensive Irrigation System at East Shewa Zone, Oromia, Ethiopia, international journal of engineering research \& technology volume 09 , issue 03 .

[11] Assefa S, Kedir Y, Alamirew, T. 2017. Effect of slopes, furrow lengths and inflow rates on irrigation performances and yield of sugarcane plantation at Metehara, Ethiopia. Irrigation drainage sys eng, 6: 179.

[12] Tesfaye Tefera Yigezu, Kannan Narayanan, Tilahun Hordof. 2016. Effect of Furrow Length and Flow Rate on Irrigation Performances and Yield of Maize, international journal of engineering research \& technology, Volume 05, Issue 04. 
[13] Mulu brehan Kifle, T. G. Gebremicael, Abbadi Girmay, Teferi Gebremedihin. 2017. Effect of surge flow and alternate irrigation on the irrigation efficiency and water productivity of onion in the semi-arid areas of North Ethiopia, Agricultural Water Management, Volume 187, Pages 69-76.

[14] Di Wu, Jingyuan Xue, Xiaodong Bo, Weichao Meng, Youjie $\mathrm{Wu}$ and Taisheng Du. 2017. Simulation of Irrigation
Uniformity and Optimization of Irrigation Technical Parameters Based On the SIRMOD Model under Alternate Furrow Irrigation. Irrig. and Drain. 66: 478-491.

[15] Eduardo A. Holzapfel, Carlos L, Migue A. Mariño, Jerónimo P, José L. Arumí, and Max B. 2010. Furrow Irrigation Management and Design Criteria Using Efficiency Parameters and Simulation Models. Chilean Journal of Agricultural Research 70 (2): 287-296. 